\title{
Co-movements in stock market returns, Ireland and London I 869-I929
}

\author{
REBECCA STUART \\ Central Bank of Ireland
}

\begin{abstract}
This article studies the relationship between the Irish and London stock markets over the period I 869 to 1929, using monthly data on capital gains. A bivariate GARCH model shows that there were significant volatility spillovers from the London to the Irish market, but not vice versa. This suggests that shocks originating in London were transmitted to Ireland, but that the reverse did not occur. Furthermore, the time-varying correlation indicates that the co-movement between London and Ireland declined during the Irish independence struggle and the establishment of the Irish Free State. The correlation appears to stabilise in the late I920s.
\end{abstract}

Keywords: stock returns, multivariate GARCH models

JEL classification: $\mathrm{G}_{1}, \mathrm{~N}_{2}$

This article provides the first in-depth study of the co-movement between the Irish and London stock markets over the period I 869 to I929. Using a BEKK GARCH model with monthly data on the capital gains in Ireland and London, it shows that developments in the London exchange had a large impact on those in Ireland. Specifically, there were significant volatility spillovers from London to Ireland, suggesting that shocks experienced in London were transmitted to the Irish market. In addition, there were significant changes in the degree of co-movement of the capital gains over time, as measured by the time-varying correlation between the series.

R. Stuart, Monetary Policy Division, Central Bank of Ireland; email: rebecca.stuart@centralbank.ie. The views expressed in this article are solely my own. I thank Gabriel Fagan, Stefan Gerlach, Richard Grossman, Morgan Kelly, Peter Kugler, Cormac Ó Gráda, Kevin O’Rourke, John Turner, participants at the Economic and Social History Society of Ireland's Annual Conference, November 20I 4, and at the Central Bank of Ireland Economic History Workshop 20I5, and three anonymous referees for helpful comments. I also thank Ronan Lyons for kindly providing data for Ireland, Ryland Thomas for a very useful discussion of London data, and Gareth Campbell for kindly compiling a series from the database of Campbell and Rogers (2017). 
While there are historical studies of the British ${ }^{1}$ and Irish $^{2}$ equity markets individually, and a number that consider the bilateral relationship between British equity markets and those in other countries, ${ }^{3}$ there is no comprehensive study of the historical relationship between Irish and British markets. ${ }^{4}$ Nonetheless, the comparison is a natural one, given the relationship between the two economies during this period. Although numerous studies have argued that the period is marked by exceptional capital market integration, ${ }^{5}$ the relationship between the Irish and British economies was, perhaps, unusually close, if not unique. As noted in McLaughlin (forthcoming), during this period the Irish economy operated in integrated commodity, capital and labour markets with Britain. A motivation for this article is to better understand how this integration manifested itself in the behaviour of the London and Irish stock markets. As by far the larger market, it seems likely that developments on the London exchange had considerable influence on those in Ireland. Did volatility in London spillover to Ireland? How closely did the markets move?

Furthermore, the period is of particular interest since it covers the disintegration of the political union between Ireland and Britain. The establishment of the Irish Free State in I922, following a number of years of conflict, did not particularly alter the market integration referred to above, but is likely, through the economic uncertainty it created and the political independence that it gave the Free State Government to pursue its own economic and financial policies, to have had some impact on the relationship between the two markets.

For instance, there is evidence that the years of conflict led to economic disruption. Boycotts and strikes were a feature of this period, while reprisals included the looting and burning of homes and businesses. ${ }^{6}$ Thus, the period saw enormous harm both in terms of lives lost and infrastructural damage. The monetary value of this loss of human and physical capital is hard to quantify: McLaughlin (forthcoming) notes that a crude estimate of the cost of the Civil War of a minimum of $650 \mathrm{~m}$ made by Patrick Hogan during a Dáil debate in September I923 equated to approximately 32 per cent of estimated national output I926. Overall, Thomas (I986, p. I82) notes that the economic 'effects [of the post-War recession] were prolonged by the political turmoil surrounding the formation of the new State'.

Furthermore, there was a period of adjustment after the establishment of the Free State. The new government had difficulty collecting taxes, and had to rely on

1 For instance, Grossman (2002), Acheson et al. (2009).

2 Grossman et al. (20I4), Hickson and Turner (2005, 2008).

3 Sylla et al. (2006), Campbell and Rogers (2017), Garbade and Silber (1978), Hoag (2006) and Neal (I987).

4 Campbell et al. (2016) consider the relationship between the London and 'provincial' exchanges, of which the Irish exchanges are part, over the period I 869-I929; however, the individual relationships of the provincial exchanges with London are not a focus of the article.

5 See, Bordo and Meissner (2015), Obstfeld and Taylor (2005) and Baldwin and Martin (I999).

${ }^{6}$ Fitzpatrick (1998). 
short-term borrowing from Irish banks initially. ${ }^{7}$ In addition, the Free State Government began to introduce policies which could lead to a divergence between the Irish and London stock markets. For instance, the Trade Loans (Guarantee) Act of 1924 provided a government guarantee on bank loans to businesses, ${ }^{8}$ a scheme that was likely to have directed businesses seeking finance away from the stock market and towards banks.

On the other hand, there remained strong economic links between Ireland and Britain after Irish independence. The labour markets were integrated, to the extent that it has been argued that there was an equilibrium relationship between the two markets which was maintained through the "safety valve' ${ }^{9}$ of emigration from Ireland to Britain. ${ }^{10}$ Trade links remained also very strong. Barry and Daly (20 I , p. I) note that following independence in I922, Ireland traded 'almost exclusively with the UK'. Furthermore, since the Free State did not immediately issue its own currency and, when it finally did introduce the Irish punt, maintained a rigid onefor-one link with sterling. As a result, capital markets continued to be integrated.

Overall, the impact of Irish independence on the relationship with the London market is not clear-cut. Although there are factors that suggest the relationship between the two markets may have changed after Irish independence, others point to a degree of continuity. Thus, the second motivation for this article is to understand the effect that the Irish independence struggle and its aftermath, which here encompasses the period beginning with the Easter Rising I9I6, the Anglo-Irish War I9I9-2I, the Irish Civil War I922-3 and the early years of the Irish Free State, had on the extent of co-movement of Irish and London stock returns.

Interestingly, the few comparisons that have been made of Irish and British stock markets tend to discuss the potential impact of the Irish independence struggle in the early twentieth century. Both Hickson and Turner (2005) and Grossman et al. (20I4), having compiled indices of Irish stock prices, note some divergence between the Irish and British performance, and speculate that it is related to Irish independence. However, these papers focus largely on compiling Irish equity indices and the comparison of equity returns in Ireland and Britain forms only a small part of the analysis. Thus, the question of what impact the independence movement and its aftermath had on co-movements is not studied in any formal sense. ${ }^{11}$

7 Fanning (1978).

8 In principle, the guarantee applied to loans for capital expenditure, although in practice they tended to be used for non-investment purposes such as paying down bank debt. See Daly (I984) for a discussion.

9 Walsh (I999).

10 Honohan (I984).

11 Grossman et al. (2014) develop a monthly Irish stock market index over the period I864-I930, and compare the final data with the annual British series of Grossman (2002) which is available from I 870 to I9I4. Hickson and Turner (2005) compile stock market data for Ireland over the period I 865-I9I3, and note that the performance of the Irish index diverges from that of the British market at the end of the sample period. 
Furthermore, this is a question with echoes in the current policy debate. In the context of British negotiations to leave the EU, the impact on the British financial sector is one concern. Whether Britain chooses a 'hard' Brexit in which, broadly speaking, it leaves the European single markets for goods and labour, or a 'softer' one in which it maintains greater access to EU markets, has been a much-debated issue. The establishment of the Irish Free State can be seen as a 'soft' exit from the United Kingdom in the sense that there continued to be free movement of labour, goods and capital. As such, it may therefore provide some insights for policymakers considering the possible impact of Brexit today.

In addressing these questions, I study monthly capital gains (referred to as 'returns') in the stock markets of Ireland and London over a 60-year period. Descriptive statistics compare the returns on the two indices over the sample period. I then employ a bivariate BEKK GARCH model to understand the co-movement of prices in the two markets during the sample period. This particular GARCH specification is well suited to the task for two reasons. First, it has an explicit representation of the volatility spillovers from one market to another. Thus, it is possible to formally test the influence of volatility in London on the Irish market. Second, the model provides estimates of the time-varying correlation between the two equity returns. This allows us to consider how the co-movements of the two series have evolved over time, and specifically to consider whether this relationship changed during the Irish independence struggle and its aftermath.

The main findings are as follows. First, developments in the London exchange had a large impact on those in Ireland. The results of the model indicate that there are volatility spillovers from London to Ireland, but not vice versa. This implies that shocks experienced in London were transmitted to the Irish market, but that shocks originating in Ireland did not impact London. Moreover, the impact of lagged volatility in the London market on the Irish market was almost as large as the impact of lagged Irish volatility. Thus, it appears that the London market played an important role in developments in the Irish market.

Second, there were significant changes in the degree of co-movement of the returns over time. The time-varying correlation estimated within the GARCH model varies between -0.IO and 0.72 . Of particular interest in this regard is how the correlation changed around the time of the Irish independence movement. Interestingly, the time-varying correlation declines during the late I9IOs and I920s. Shocks to the two returns series during this period were often idiosyncratic rather than common, driving down the correlation. However, the decline in the correlation is similar to others witnessed during the sample period. This suggests that the shock associated with Irish independence was similar in size to other shocks experienced during this time and not an outlier. The correlation appears to stabilise in the late I920s.

The article is structured as follows: the next section discusses the channels through which the co-movement of stock returns can occur with reference to both theory and empirical evidence. The data are described in Section III, and some descriptive statistics are considered. Section IV presents the GARCH model, discusses the coefficient 
estimates and considers the changing relationship between the two markets as illustrated by the estimated time-varying correlation. Section v concludes.

In this section I consider why there might be co-movement between equity returns in different countries. For simplicity, consider the Gordon (I959) dividend growth model, according to which the price of a stock is determined as follows:

$$
p_{t}=\frac{D_{t}}{r-g}
$$

Here, the price, $p_{t}$, is determined by the dividend today, $D_{t}$; the growth rate of dividends (which is assumed constant), $g$; and the required rate of return, $r$, which can be thought of as the sum of the risk-free rate and the risk premium required for holding equities. The model suggests that international co-movements in prices could occur if the risk-free rate shifts in a number of countries at the same time. This could arise if there is a change in the perceived economic growth outlook across a number of countries. Alternatively, international co-movements in economic growth could lead the expected growth rate of dividends to be correlated across countries. Finally, risk premia could be reappraised across countries at the same time. These shifts could occur because of an event in one country, or in a number of countries.

The recent global financial crisis is an example of an event that triggered a reappraisal of risk across many countries. A number of studies have considered how this occurred. A study by Hwang et al. (2013) finds that contagion and herding behaviour were important in the transmission of shocks from the US to emerging economies. ${ }^{12}$ Similarly, Didier et al. (2OI2) find that financial linkages were important determinants of the co-movement of US stock returns with those in 83 other countries during the 2007-8 crisis. Grammatikos and Vermeulen (20I2) find that financial stock returns in the EMU from 2003 to 20 I o became significantly more dependent on currency risks, as measured by changes in the spread between the Greek and German CDS after the collapse of Lehman Brothers in September 2008.

I next turn to the issue of measuring the co-movements of stock returns. A variety of methods have been employed in (mostly recent) studies.

One method is to consider the correlation of stock returns. For instance, Goetzmann et al. (2005) calculate correlations of stock returns in Europe, Asia, the Americas, Africa and Australasia over long sample periods, generally beginning in the first half of the twentieth century. They find that correlations were high in the pre-First World War era, even compared to more recent times, and interpret this as evidence of integration. Similarly, Campbell and Rogers (20I7) and Campbell

12 See Triner and Wandschneider (2005) for a discussion of contagion arising from the Baring crisis in I 890 . 
et al. (2016) focus on the r-squared from a bivariate regression of one return series on another. ${ }^{13}$

Another strand of the literature seeks to identify common shocks and then estimate the co-movement of each stock market index with this shock. While many recent studies use such methods, ${ }^{14}$ few historical studies have employed them, ${ }^{15}$ possibly because common shocks can only be estimated in a comparative study including a number of indices. An exception is Stuart (2016), who uses principal component analysis and monthly data to identify a common shock across six equity markets during the classical gold standard era, and then estimates the impact of this shock on the equities in a VAR.

Other studies of modern data estimate when market integration occurs. For instance, Bekaert and Harvey (I995) use a conditional regime-switching model in which periods of greater and lesser integration between modern capital markets are identified. Bekaert, Harvey and Lumsdaine (2002) test for breaks in reduced-form financial and macroeconomic time series models for 20 emerging market countries, with identified breaks interpreted as reflecting increased integration.

An alternative approach uses generalised autoregressive conditional heteroscedasticity (GARCH) methods, which have been used extensively to model heteroscedasticity in financial data, to estimate the co-movement of the returns and volatility across markets. ${ }^{16}$ Choudhry (1995) estimates an integrated GARCH model of the persistence of stock return volatility of European indices in the I920s and I930s. The author shows that shocks to volatility are permanent for most of the indices studied. A similar GARCH approach is adopted in this article.

\section{III}

The data used in this article are for capital gains in equities in Ireland and London. The data for London are provided by Campbell and Rogers (20 I 7), while those for Ireland are from Grossman et al. (20I4). Although the data are originally from different sources, they are compiled in a consistent manner. ${ }^{17}$ Specifically, all data are sourced from the Investors Monthly Manual. Both data series are price-weighted using end-month data. Both series exclude dividends ${ }^{18}$ and listings whose primary

13 In a bivariate regression, the r-squared equals the squared correlation coefficient for the two variables. See Schotman and Zalewska (2006) for a similar study of the integration of emerging European economies and developed economies using modern data.

14 See, for instance, Chambet and Gibson (2008), Pukthuanthong and Roll (2009) and Bekaert, Hodrick and Zhang (2009).

15 Edelstein (I982) employed such methods to examine co-movements of rates of return across industries and countries over the period I 850 to I9I 4 .

16 See, for instance, Bauwens et al. (2006) and Silvennoinen and Terasvirta (2009).

17 I have established this in private correspondence with the authors.

18 The data presented in Campbell and Rogers (20I7) include dividends; however, the authors kindly provided a series exclusive of dividends. 
business activities were overseas. ${ }^{19}$ The Campbell and Rogers (20I7) data pertain to the London Stock Exchange, which the Grossman et al. (20 I4) data are composed of listings on the three Irish exchanges, Dublin, Belfast and Cork.

Following Campbell and Rogers (20I7), both data series are winsorised to lessen the impact of outliers. ${ }^{20}$ Thus, the most extreme negative values of the series are set to the level of returns at the 2.5 th percentile, and the most extreme positive values of the series are set to the level of returns at the 97.5 th percentile.

The upper panel of Figure I shows the final series used. While estimation is conducted on monthly returns, the panel shows a I2-month moving average of the series. Key episodes are visible in the data. Turning first to the London series, the negative returns in I 878 coincide with the collapse of the Glasgow City Bank. Although considered a 'non-crisis' 21 since it was not systemic, this failure had wide-ranging effects on regulation and the broader economy. ${ }^{22}$ The Barings crisis in I 890 had a less marked impact on the series. The period of strong growth in the London market during the second half of the I 890 s that is noted by Grossman (2002) is also evident.

The exchange was closed for several months following the financial crisis at the start of the First World War; however, after the initial decline, the returns recovered strongly, particularly during the post-war boom in I9I9-20 (Roberts 20I4). The negative pressures thereafter, which were at their most acute in terms of unemployment and price declines in I922, coincide with a sharp dip in the series. The re-establishment of the link to gold in I925 also led to a temporary, albeit less severe, dip in the series.

The Irish returns are clearly subject to some of the same shocks as the London series; however, idiosyncratic shocks are also notable. Thus, while the Irish series also declines in the late I870s, it begins to do so in I877 coinciding with the agricultural depression which began in that year. This decline then appears to have been accentuated by the failure of the City of Glasgow Bank the following year. Strong growth in the early I 890 s is associated with a boom in railway stocks in Ireland that is identified in Grossman et al. (2OI4). The large shocks associated with the First World War and immediate post-war period are also clearly evident in the Irish data. Interestingly, however, there is no major divergence in the growth rates of the series during the conflict period in Ireland. Nonetheless, the Irish series exhibits a higher degree of volatility during the I920s, including episodes of negative growth not present in the London data.

19 The authors of Campbell and Rogers (20I7) removed listings with primary business overseas from the series provided to me. Seven companies listed on the Irish exchanges are also listed in London. Although their business activities were primarily in Ireland, rather than Britain, these are also removed from the Irish index to avoid issues of cross-listing.

20 The authors kindly provided the underlying data from Grossman et al. (2OI4) so that price-weighting and winsorising could be calculated.

21 Capie (20I4).

22 Turner (20I4), Acheson and Turner (2008) and Button et al. (20 I 5). 
(a) 12-month moving average returns

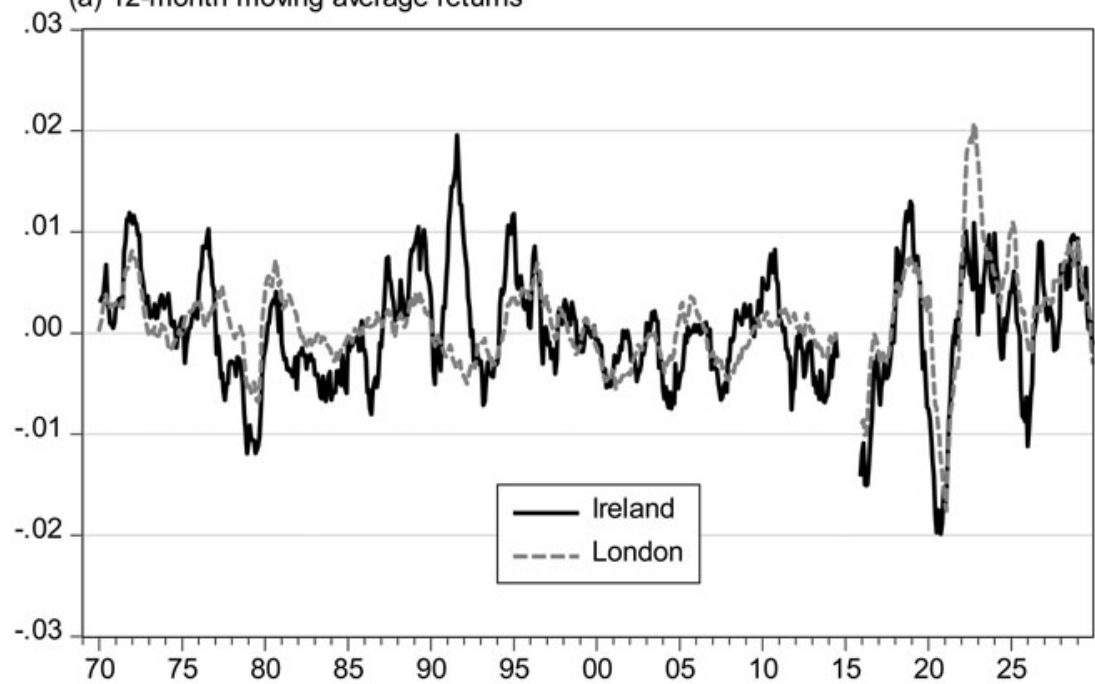

(b) Time-varying correlations

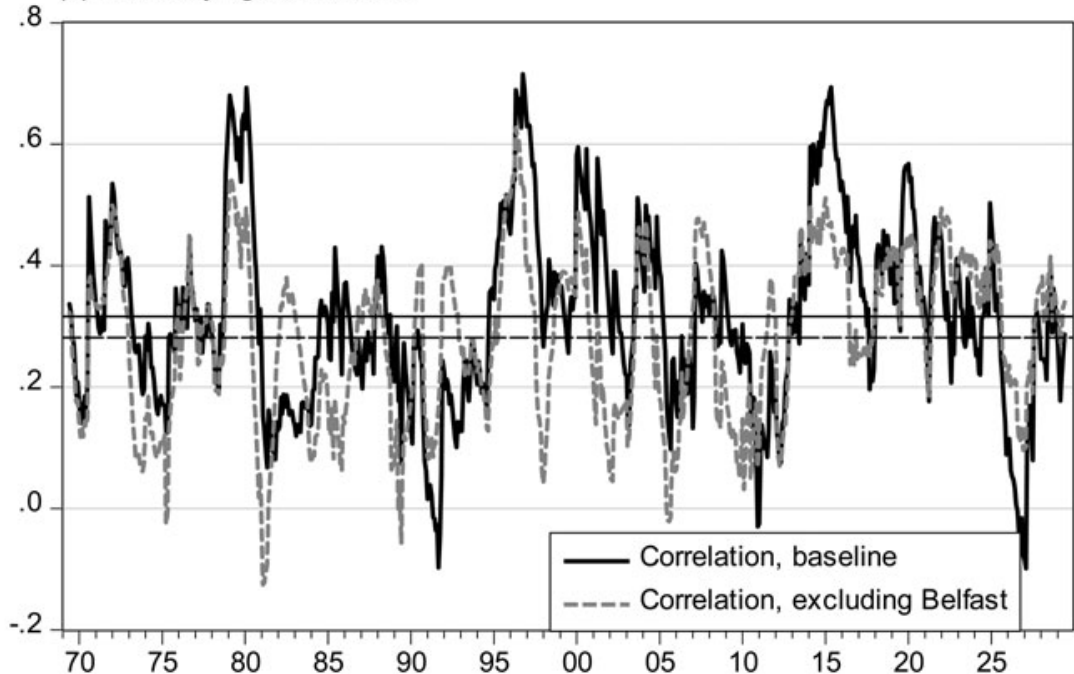

Figure I. London and Irish returns

Note: The solid horizontal line in the lower panel represents the average estimated correlation (o.32) over the sample period. The dashed horizontal line in the lower panel represents the average estimated correlation (0.28) over the period, when Belfast listings are excluded.

Table I shows the average returns and variances of the indices over the full sample, and three 20-year subsamples. Turning first to average returns, it is important to recall that they exclude dividends and therefore do not represent the overall return to an investor. Overall, the Irish series exhibits a lower mean monthly return for the full period: 0.02 per cent for the Irish series compared to 0.08 per cent on the London 
Table 1. Descriptive statistics, monthly returns, 1869-1929

\begin{tabular}{llllll}
\hline \hline & \multicolumn{2}{c}{ Average return, in $\%$} & & \multicolumn{2}{c}{ Variance } \\
\cline { 2 - 3 } & London & Ireland & & London & Ireland \\
\hline Full sample & 0.075 & 0.015 & & 0.690 & 2.358 \\
I 869-89 & 0.116 & 0.043 & & 0.365 & I.738 \\
I 890-1909 & -0.073 & 0.043 & & 0.333 & I.723 \\
I910-29 & 0.179 & $-0.03 \mathrm{I}$ & & I.307 & 3.516 \\
\hline \hline
\end{tabular}

series. Looking across the subperiods, average returns in London are higher in the first and final subperiods. Although average returns on the Irish series are higher only in the second subperiod (corresponding to the period of particularly strong growth in Irish railways), they are negative in the final subperiod, which is perhaps surprising given the stock market boom elsewhere during the I920s. In the context of the Irish independence movement, it is notable that this strong price growth in London and falling prices in the Irish exchanges in the final subperiod may be consistent with impending home rule and/or the actual conflict around independence and partition. Turning to the variances, the Irish returns display a higher variance for the full sample, and across all three subperiods. For both series, the variance is nearly unchanged across the first two subperiods, but rises considerably in the final subperiod.

To formally consider the co-movement of returns during this period, I next estimate a bivariate GARCH model. These models are useful when considering financial data, since they often display heteroscedastic volatility that is predictable through time. ${ }^{23}$ Here, I use the BEKK GARCH (I,I) framework set out in Engle and Kroner (I995). Unlike other, more parsimonious, GARCH frameworks the BEKK framework includes a representation that allows for volatility spillovers from one market to another. Furthermore, unlike some other specifications such as constant conditional correlation models, BEKK models assume that the correlation between series varies through time. This correlation can be used to consider how the co-movement of the series changed over the 6o-year sample period.

${ }^{23} \mathrm{ARCH}$ effects can be tested for by regressing each return series on its own lag and the lag of the other series. The residuals series are retrieved and squared, and then regressed on its lag. The null hypothesis is that $\mathrm{ARCH}$ effects are not present, and therefore that the parameter on the squared lagged term is equal to zero. The null can be rejected for both series ( $p$-values of 0.00 ). 
The BEKK GARCH $(\mathrm{I}, \mathrm{I})$ model can be written as:

$$
\begin{gathered}
y_{t}=\beta x_{t}+\epsilon_{t} \\
\epsilon_{t} \sim N\left(0, H_{t}\right) \\
H_{t}=A^{\prime} H_{t-1} A+B^{\prime} \epsilon_{t-1}^{\prime} \epsilon_{t-1} B+C^{\prime} C
\end{gathered}
$$

Where $y_{t}$ is a vector of dependent variables (monthly equity returns in our case), $\beta$ is a matrix of coefficients, $x_{t}$ is a vector of independent variables (which in our case are lagged own returns) and $\epsilon_{t}$ is the vector of error terms, which is normally distributed with zero mean and a variance-covariance structure described by $H_{t}$. In our bi-variate case, where the Irish market is denoted by I, and the London market by $\mathrm{L}, H_{t}$ can be written as:

$$
H_{t}=\left[\begin{array}{cc}
h_{I, t} & h_{I L, t} \\
h_{L I, t} & h_{L, t}
\end{array}\right]
$$

where the variances are given by the diagonal elements, $h_{I}$ and $h_{L}$, and the covariances are given by the off-diagonal elements. The covariances are symmetric such that $h_{I L, t}=h_{L I, t}$.

From equation (2), the current variance, $H_{t}$, is determined by lagged variance, lagged residuals and a constant term. The matrix containing the constant terms, $C$, is lower triangular. Thus, in the bivariate case the model takes the following form:

$$
\begin{gathered}
H_{t}=\left[\begin{array}{ll}
a_{11} & a_{12} \\
a_{21} & a_{22}
\end{array}\right]{ }^{\prime} H_{t-1}\left[\begin{array}{ll}
a_{11} & a_{12} \\
a_{21} & a_{22}
\end{array}\right]+\left[\begin{array}{ll}
b_{11} & b_{12} \\
b_{21} & b_{22}
\end{array}\right],\left[\begin{array}{cc}
e_{I, t-1}^{2} & e_{I, t-1} e_{L, t-1} \\
e_{L, t-1} e_{I, t-1} & e_{L, t-1}^{2}
\end{array}\right] \\
{\left[\begin{array}{ll}
b_{11} & b_{12} \\
b_{21} & b_{22}
\end{array}\right]+\left[\begin{array}{cc}
c_{11} & 0 \\
c_{21} & c_{22}
\end{array}\right],\left[\begin{array}{cc}
c_{11} & 0 \\
c_{21} & c_{22}
\end{array}\right]}
\end{gathered}
$$

Solving this equation, the Irish and London variances take the following form:

$$
\begin{aligned}
h_{I, t}= & a_{11}^{2} h_{I, t-1}+2 a_{11} a_{21} h_{I L, t-1}+a_{21}^{2} h_{L, t-1}+b_{11}^{2} e_{I, t-1}^{2}+2 b_{11} b_{21} e_{I, t-1} e_{L, t-1} \\
& +b_{21}^{2} e_{L, t-1}^{2}+c_{11}^{2} \\
h_{L, t}= & a_{22}^{2} h_{L, t-1}+2 a_{22} a_{12} h_{I L, t-1}+a_{12}^{2} h_{I, t-1}+b_{22}^{2} e_{L, t-1}^{2}+2 b_{22} b_{12} e_{I, t-1} e_{L, t-1} \\
& +b_{12}^{2} e_{I, t-1}^{2}+c_{21}^{2}+c_{22}^{2}
\end{aligned}
$$

Thus, own lagged variance (referred to as the GARCH term) and own squared residuals (referred to as the ARCH term) affect current own variance. Furthermore, the lagged variance (referred to as GARCH spillovers) and squared residuals (referred to as ARCH spillovers) of the one series, as well as lagged covariance and residual crossproducts, affect the variance of the other series, and vice versa. This framework will be used to consider the effect of volatility spillovers between the London and Irish markets. 
The covariance is given by:

$$
\begin{aligned}
h_{I L, t}=h_{L I, t}= & a_{11} a_{12} h_{I, t-1}+\left(a_{11} a_{22}+a_{12} a_{21}\right) h_{I L, t-1}+a_{22} a_{21} h_{L, t-1} \\
& +b_{11} b_{12} e_{I, t-1}^{2}+\left(b_{11} b_{22}+b_{12} b_{21}\right) e_{I, t-1} e_{L, t-1}+b_{22} b_{21} e_{L, t-1}^{2}+c_{11} c_{22}
\end{aligned}
$$

As such, the covariance depends on lagged covariance and lagged variances of both series, lagged residuals and the cross-product of lagged residuals.

Finally, the exchanges were closed following the outbreak of the First World War. Thus, the months from August I9I 4 to February I9I5 are dropped from the sample for estimation. However, setting the observations for the series to zero during these months has no significant impact on the results. Equally, maintaining a constant growth rate throughout the period of closure that is equal to the growth rate at the end of the last month prior to closure has little impact on the results.

The results of this model are presented in Table 2. The upper panel shows the results of the mean equations (equation (I)) which are estimated using one lag of own returns to allow for any autocorrelation of the returns. The lower panel shows the results for the variance equations. In interpreting these results, it is useful to recall from equations (3) and (4) that the coefficients of the own ARCH and GARCH terms are $a_{11}, a_{22}, b_{11}$ and $b_{22}$, while those coefficients capturing volatility spillovers from one series to the other are primarily $a_{\mathrm{I} 2}, a_{2 \mathrm{I}}, b_{\mathrm{I} 2}$ and $b_{2 \mathrm{I}}$. Four features of the results are notable.

First, all the own ARCH and GARCH terms (the coefficients on lagged own residuals and lagged own variance, respectively), $a_{\mathrm{II}}, a_{22}, b_{\mathrm{II}}$ and $b_{22}$, are highly significant, indicating that both $\mathrm{ARCH}$ and $\mathrm{GARCH}$ effects are present, and that the specification is a reasonable one. Since $a_{11}$ and $a_{22}$ are both greater than 0.9, it means that there is a large degree of persistence in the variance.

Second, $a_{12}$ is not significant but $a_{21}$ is. This result indicates that GARCH spillovers occur only from London to the Irish market and not vice versa. That is, lagged variance of the London market impacts current variance of the Irish market. Indeed, it is notable that $a_{2 \mathrm{I}}$ is almost as large as the Irish own GARCH term, $a_{\mathrm{II}}$. This suggests that GARCH spillovers from London are almost as important as own Irish GARCH volatility in determining the variance of the Irish series. ${ }^{24}$

Similarly, $b_{2 \mathrm{I}}$ is significant, indicating that there are ARCH spillovers from London to Ireland, but $b_{\mathrm{I} 2}$ is not significant, indicating that spillovers do not occur in the opposite direction. Taken together, these two results fit with prior expectations of

24 The sign of some of the coefficients is negative. Since the calculation of direct spillovers is based on the squared coefficients (equations (3) and (4)), this is not important. However, in equations (3) and (4) these coefficients also appear in the terms for cross-product of the lagged residuals/lagged covariances. Here it is important to remember that the size of the coefficients is small, and that while statistically significant, economically they have a small effect, particularly when used multiplicatively. 
Table 2. Bivariate GARCH: estimates of mean and variance equations, 1869-1929

\begin{tabular}{|c|c|c|}
\hline & \multicolumn{2}{|c|}{ Mean equations } \\
\hline & Irish returns & London returns \\
\hline Lagged Irish returns & $\begin{array}{r}0.056 \\
(0.036)\end{array}$ & \\
\hline Lagged London returns & & $\begin{array}{l}0.347^{\star \star \star} \\
(0.034)\end{array}$ \\
\hline \multirow[t]{2}{*}{ Constant } & $\begin{array}{c}-0.000 \\
(0.00 \mathrm{I})\end{array}$ & $\begin{array}{c}0.000 \\
(0.000)\end{array}$ \\
\hline & \multicolumn{2}{|c|}{ Variance equation estimates } \\
\hline $\mathrm{a}_{\mathrm{II}}$ & \multicolumn{2}{|c|}{$\begin{array}{c}0.963^{\star \star \star} \\
(0.016)\end{array}$} \\
\hline$a_{22}$ & \multicolumn{2}{|c|}{$\begin{array}{c}0.946^{\star \star \star} \\
(0.017)\end{array}$} \\
\hline$a_{12}$ & \multicolumn{2}{|c|}{$\begin{array}{c}0.001 \\
(0.007)\end{array}$} \\
\hline$a_{21}$ & \multicolumn{2}{|c|}{$\begin{array}{c}-0.160^{\star \star \star} \\
(0.053)\end{array}$} \\
\hline $\mathrm{b}_{\mathrm{II}}$ & \multicolumn{2}{|c|}{$\begin{array}{c}\text { O.I } 55^{\star \star \star} \\
(0.034)\end{array}$} \\
\hline$b_{22}$ & \multicolumn{2}{|c|}{$\begin{array}{c}0.272^{\star \star \star} \\
(0.044)\end{array}$} \\
\hline$b_{12}$ & \multicolumn{2}{|c|}{$\begin{array}{r}-0.014 \\
(0.015)\end{array}$} \\
\hline$b_{2 I}$ & \multicolumn{2}{|c|}{ (O.IO4) } \\
\hline$c_{\text {II }}$ & \multicolumn{2}{|c|}{$\begin{array}{c}0.003^{\star \star \star} \\
(0.001)\end{array}$} \\
\hline $\mathrm{c}_{\mathrm{I} 2}$ & \multicolumn{2}{|c|}{$\begin{array}{c}\mathrm{O} .00 \mathrm{I} \star \star \star \\
(0.000)\end{array}$} \\
\hline $\mathrm{c}_{22}$ & \multicolumn{2}{|c|}{$\begin{array}{c}0.000 \\
(0.001)\end{array}$} \\
\hline
\end{tabular}

Notes: $\star \star \star, \star \star$ and $\star$ indicate significance at the $\mathrm{I} \%, 2.5 \%$ and $5 \%$ levels respectively. Standard errors in parenthesis.

the direction of spillovers as being unidirectional from London to Ireland, given the relative size and importance of the markets.

Finally, $a_{2 \mathrm{I}}$ and $b_{2 \mathrm{I}}$ are much larger in size than $a_{\mathrm{I} 2}$ and $b_{\mathrm{I} 2}$, respectively. This implies that in the calculation of the covariance of the series, lagged London variance 
and squared residuals are more important than lagged Irish variance and squared residuals.

In addition to these estimated coefficients, the model also allows the construction of time-varying variances and covariances. From these, a time-varying correlation between the series can be calculated. I focus on this correlation below, since it provides an indicator of the co-movement of the series throughout the sample period.

The time-varying correlation for this baseline specification is presented in the lower panel of Figure I (solid black line). Over the entire period the average correlation is 0.32 (solid horizontal line). However, there is significant variation in the correlation over the sample period, which ranges from -0.IO to 0.72 . Interestingly, both the maximum and minimum values of the correlation occur in I920s.

To understand what is driving these changes in the correlation, it is helpful to consider them in the context of the I2-month moving average of returns in the upper panel of Figure I. It is important to note that the time-varying correlations are simply the estimated data, not a I2-month moving average like the average returns. Nonetheless, the comparison can be informative.

Unsurprisingly, the correlation rises around the time of the failure of the City of Glasgow Bank. The strong growth in the Irish series in the early I 890 os resulted in a low in the correlation between the series. The correlation rises again as both series grow strongly in the late i89os. Thereafter, the correlation declines and varies around average for much of the I9oos. The First World War is a common shock, which drives up the correlation of the series. The correlation remains high temporarily after the reopening of the exchanges in early I9I5. Thereafter, the correlation becomes very volatile, with temporary sharp rises associated with common shocks during the post-war economic difficulties in the early I920s and the return to the gold standard in 1925 offset by sharp declines in between.

Overall during the period from the end of the I9Is to the late I920s, the trend in the correlation is downward, reaching a low in I927. Interestingly, there are no sharp declines in the correlation associated with specific events in the Irish independence movement - for instance, following the Easter Rising in I9I6. Instead, the decline is gradual but continual over the time period. However, the general declining trend suggests that there are idiosyncratic shocks driving down the correlation in the series during the period of the Irish independence struggle and the early years of the Free State.

Nonetheless, although the correlation declines, it is not particularly different from other periods of low correlation during the sample period. Thus, although events during this period appear to have driven the indices apart, the size of the shock associated with the independence movement was not particularly dissimilar from other periods in the sample. Furthermore, towards the end of the sample the correlation recovers somewhat and settles near $0.3-0.35$, close to the sample average. Although a longer sample period would be required to investigate whether this was a longrun pattern, it appears that the relationship may have been returning to 'normal' after a number of years once the Irish Free State was more firmly established. 
The Irish series is composed of data for firms listed on the Dublin, Cork and Belfast exchanges. Since the results above suggest that the decline in the correlation of Irish and London equities coincided with the Irish independence struggle and the establishment of the Irish Free State, it is interesting to remove the Belfast-listed stocks from the series, even though such a series is only representative of the political boundaries in place for the period I922-9. In total I 8 listings are removed. ${ }^{25}$ Nonetheless, it is likely that some remaining listings carried out cross-border trade, so there may not be an exact delineation of the data between Free State and Northern Ireland.

The same specification is used as previously, and the estimated coefficients are reported in Table 3. The estimated time-varying correlation follows a very similar pattern to that for the baseline specification (dashed grey line in the lower panel of Figure I); the correlation coefficient between the two series is 0.66. Nonetheless, the average correlation excluding Belfast listings is marginally lower than the baseline (0.28 compared to 0.32 , dashed horizontal line). This is evident from the fact that the correlation excluding Belfast listings is rarely higher than the baseline correlation; however, it is lower at several points in the sample period.

The lower overall correlation of the series excluding Belfast listings with the London market means that the decline in correlation around the time of the independence movement is slightly less marked. This suggests that, since the correlation was already lower for those Irish companies listed outside Belfast, the effect of the independence movement was marginally less severe, compared to historical episodes. Nonetheless, the patterns of the two correlations are similar during this period, indicating that the Belfast listings and Free State listings were affected by similar events and uncertainty during the time. This is perhaps unsurprising considering that during the Anglo-Irish War, the futures of the Northern and Southern counties were similarly uncertain, while following partition, the border was new and the political and economic relationships between North and South were untested.

\section{V}

The historical relationship between the stock markets in London and Ireland has not, to my knowledge, been the focus of any previous study. However, the relationship between the two is naturally of interest given the close economic and financial ties between Ireland and Britain. This article addressed this gap, studying monthly data on equity returns from the two markets over the period I869-I929. This period is of particular interest since it includes the transition of Southern Ireland from a 'provincial' British market to that of the Irish Free State.

This article considers the relationship between the Irish and London stock markets, first through descriptive statistics, and second using a bivariate BEKK GARCH

25 One listing in the original Grossman et al. (2O I4) index was already removed, as it was also listed on the London exchange. 
Table 3. Bivariate GARCH: estimates of mean and variance equations, excluding Belfast listed stocks

\begin{tabular}{lcc}
\hline \hline & \multicolumn{2}{c}{ Mean equations } \\
\cline { 2 - 3 } & Irish returns & London returns \\
\hline Lagged Irish returns & 0.042 & \\
Lagged London returns & $(0.035)$ & $0.368 \star \star \star$ \\
Constant & & $(0.033)$ \\
& 0.000 & 0.000 \\
& $(\mathrm{O}) \mathrm{OoI})$ & $(0.000)$ \\
\hline
\end{tabular}

Variance equation estimates

\begin{tabular}{|c|c|}
\hline$a_{I I}$ & $\begin{array}{c}0.999^{\star \star \star} \\
(0.014)\end{array}$ \\
\hline $\mathrm{a}_{22}$ & $\begin{array}{c}0.938^{\star \star \star} \\
(0.014)\end{array}$ \\
\hline $\mathrm{a}_{\mathrm{I} 2}$ & $\begin{array}{c}0.027^{\star \star \star} \\
(0.006)\end{array}$ \\
\hline$a_{2 \mathrm{I}}$ & $\begin{array}{c}-0.240^{\star \star \star} \\
(0.050)\end{array}$ \\
\hline $\mathrm{b}_{\mathrm{II}}$ & $\begin{array}{c}\text { O.I } 39^{\star \star \star} \\
(0.034)\end{array}$ \\
\hline $\mathrm{b}_{22}$ & $\begin{array}{c}0.207^{\star \star \star} \\
(0.038)\end{array}$ \\
\hline$b_{\mathrm{I} 2}$ & $\begin{array}{c}-0.029^{\star \star} \\
(0.012)\end{array}$ \\
\hline$b_{2 I}$ & $\begin{array}{c}0.36 I^{\star \star \star} \\
(0.106)\end{array}$ \\
\hline $\mathrm{c}_{\mathrm{II}}$ & $\begin{array}{l}0.000 \\
(0.199)\end{array}$ \\
\hline$c_{12}$ & $\begin{array}{l}0.000 \\
(\mathrm{I} .37 \mathrm{I})\end{array}$ \\
\hline$c_{22}$ & $\begin{array}{l}-0.001 \\
(0.144)\end{array}$ \\
\hline
\end{tabular}

Notes: $\star \star \star, \star \star \star$ and $\star$ indicate significance at the I $\%, 2.5 \%$ and $5 \%$ levels respectively. Standard errors in parenthesis.

model. The BEKK framework is particularly appropriate as it includes a representation for volatility spillovers between the two markets, and it estimates time-varying correlations. Combined, these enable the study of the co-movement of the two series and how it changed over time. 
The overall conclusions of the article are as follows. First, the London market had a large and significant impact on the Irish market. In particular, there were significant volatility spillovers from London to Ireland. Overall, it appears that shocks experienced in London were transmitted to the Irish market.

Second, the correlation of the series varies considerably over the sample period. Periods of high correlation, such as during the failure of the City of Glasgow Bank and the First World War, result in correlations in excess of o.6. However, in other periods, correlations are much lower, and sometimes negative.

The correlation of the two markets declines during the late I9Ios and I920s. This finding suggests that the Irish independence struggle and its aftermath reduced the comovement of the two indices. Furthermore, it may also provide some insight into the potential impact of Brexit today. Although the Irish Free State was established following a period of conflict, the capital, labour and goods markets continued to operate much as before. Therefore, in some respects Irish independence was close to a 'soft' exit and could be considered a lower bound for the effect of possible Brexit scenarios.

Against this background, the decline in co-movement between the Irish and London markets during this period suggests that they were experiencing more idiosyncratic shocks. However, although the general decline in correlation is marked, the overall level of the correlation is not much below that seen at other points in the sample. Thus, the shock of the independence struggle and establishment of the Irish Free State is not a complete outlier. Furthermore, there are tentative signs of a stabilisation in the correlation towards the end of the sample period.

Submitted: 23 May 2016

Revised version submitted: I7 March 2017 and 4 June 2017

Accepted: 9 June 2017

\section{References}

ACHESON, G., HICKSON, C., TURNER, J. and YE, Q. (2009). Rule Britannia! British stock market returns, I825-I870. Journal of Economic History, 69(4), pp. I I07-37.

ACHESON, G. and TURNER, J. (2008). The death blow to unlimited liability in Victorian Britain: the City of Glasgow failure. Explorations in Economic History, 45(3), pp. $235-53$.

BALDWIN, R. and MARTIN, P. (I999). Two waves of globalisation: superficial similarities, fundamental differences. NBER Working Papers Series, Working Paper 6904, January.

BARRY, F. and DALY, M. (2OI I). Irish perceptions of the Great Depression. Institute for International Integration Studies Discussion Paper no. 349.

BAUWENS, L., LAURANT, S. and ROMBOUTS, J. (2006). Multivariate GARCH models: a survey. Journal of Applied Econometrics, 2I, pp. 79-IO9.

BEKAERT, G. and HARVEY, C. (I995). Time-varying world market integration. Journal of Finance, 50(2), pp. 403-44.

BEKAERT, G., HARVEY, C. and LUMSDAINE, R. (2002). Dating the integration of world equity markets. Journal of Financial Economics, 65(2), pp. 203-47.

BEKAERT, G., HODRICK, R. and ZHANG, X. (2009). International stock return co-movements. Journal of Finance, 63(6), pp. 259I-626. 
BORDO, M. and MEISSNER, C. (20I 5). Financial globalisation, financial development and financial crises in the golden age, I870-I9I4. Paper prepared for the conference 'Financial Systems and Economic Growth: Conference in Honor of Richard Sylla', Stern School of Business, New York University, March 27-28.

BUTTON, R., KNOTT, S., MACMANUS, C. and WILLISON, M. (2015). Desperate adventurers and men of straw: the failure of City of Glasgow Bank and its enduring impact on the UK banking system. In Bank of England, Quarterly Bulletin 2015 Q1, pp. 23-35.

CAMPBELL, G. and ROGERS, M. (20I7). Integration between the London and New York Stock Exchanges, I 825-I925. Economic History Review, DOI io. I I I /ehr. I2423, February.

CAMPBELL, G., ROGERS, M. and TURNER, J. (20I6). The rise and decline of the UK's provincial stock market, I 869-I929. QUCEH working paper series, 2016-3, May.

CAPIE, F. (2OI4). British financial crises in the nineteenth and twentieth centuries. In N. Dimsdale and A. Hotson (eds.), British Financial Crises since 1825. Oxford: Oxford University Press.

CHAMBET, A. and GIBSON, R. (2008). Financial integration, economic integration and trade structure in emerging markets. Journal of International Money and Finance, 27(4), pp. 654-75.

CHOUDHRY, T. (I995). Integrated-GARCH and non-stationary variances: evidence from European stock markets during the I920s and I930s. Economics Letters, 48, pp. 55-9.

DALY, M. (I984). Government finance for industry in the Irish Free State: the Trade Loans (Guarantee) Acts. Irish Economic and Social History, II, pp. 73-93.

DIDIER, T., LOVE, I. and SOLEDAD MARTINEZ PERIA, M. (2O I 2). What explains co-movement in stock market returns during the 2007-2008 crisis? International Journal of Finance and Economics, I7(2), pp. I $82-202$.

EDELSTEIN, M. (1982). Overseas Investment in the Age of High Imperialism: The United Kingdom, 1850-1914. London: Columbia University Press.

ENGLE, R. and KRONER, K. (I995). Multivariate simultaneous generalized arch. Econometric Theory, II (I), pp. I22-50.

FANNING, R. (1978). The Irish Department of Finance, 1922-58. Dublin: Institute of Public Administration.

FITZPATRICK, D. (I998). The Two Irelands 1912-1939. Oxford: Oxford University Press.

GARBADE, K. and SILBER, W. (I978). Technology, communication and the performance of financial markets: I 840-I975. Journal of Finance, 33(3), pp. 8I9-32.

GOETZMANN, W., LI, L. and ROUWENHORST, K. (2005). Long-term global market correlations. Journal of Business, $78(\mathrm{I})$, pp. I-38.

GORDON, M. J. (I959). Dividends, earnings and stock prices. Review of Economics and Statistics, 4I(2), pp. 99-I05.

GRAMMATIKOS, T. and VERMEULEN, R. (20 I2). Transmission of the financial and sovereign debt crises to the EMU: stock prices, CDS spreads and exchange rates. Journal of International Money and Finance, 3I(3), pp. 5I7-33.

GROSSMAN, R. (2002). New indices of British equity prices, I870-I9I 3. Journal of Economic History, 62 (I), pp. I2 I-46.

GROSSMAN, R., LYONS, R., O'ROURKE, K. and URSU, M. (20I4). A monthly stock exchange for Ireland, I864-I930. European Review of Economic History, I8(3), pp. 248-76.

HICKSON, C. and TURNER, J. (2005). The rise and decline of the Irish stock market, I865-I9I 3. European Review of Economic History, 9, pp. 2-33.

HICKSON, C. and TURNER, J. (2008). Pre- and post-famine indices of Irish equity prices. European Review of Economic History, I2, pp. 3-38.

HOAG, C. (2006). The Atlantic telegraph cable and capital market information flows. Journal of Economic History, 66(2), pp. 342-53.

HONOHAN, P. (I984). The evolution of the rate of unemployment in Ireland, I962-83. ESRI, Quarterly Economic Commentary, pp. 45-59.

HWANG, E., MIN, H., KIM, B. and KIM, H. (20I3). Determinants of stock market co-movements among US and emerging economies during the US financial crisis. Economic Modelling, 35, pp. 338-48.

MCLAUGHLIN, E. (Forthcoming). Economic impact of the Irish revolution. In J. Crowley, D. Drisceoil, M. Murphy and J. Borgonovo (eds.), Atlas of the Irish Revolution. Cork: Cork University Press. 
OBSTFELD, M. and TAYLOR, A. (2005). Global Capital Markets: Integration, Crisis, and Growth. Cambridge: Cambridge University Press.

PUKTHUANTHONG, K. and ROLL, R. (2009). Global market integration: an alternative measure and its application. Journal of Financial Economics, 94(2), pp. 21 4-32.

ROBERTS, R. (20I4). How we saved the city: the management of the financial crisis of I9I4. In N. Dimsdale and A. Hotson (eds.), British Financial Crises since 1825. Oxford: Oxford University Press.

SCHOTMAN, P. and ZALEWSKA, A. (2006). Non-synchronous trading and testing for market integration in Central European emerging markets. Journal of Empirical Finance, I3 (4-5), pp. 462-94.

SILVENNOINEN, A. and TERASVIRTA, T. (2009). Multivariate GARCH models. In T. Andersen, R. Davis, J. Kreiss and T. Mikosch (eds.), Handbook of Financial Time Series. Berlin and Heidelberg: Springer.

STUART, R. (20I6). International stock market integration during the Gold Standard. Working paper.

SYLLA, R., WILSON, J. and WRIGHT, R. (2006). Integration of Trans-Atlantic capital markets, I790-I 845. Review of Finance, Io(4), pp. 6I 3-44.

THOMAS, W. (1986). The Stock Exchanges of Ireland. Liverpool: Francis Cairns Publications.

TRINER, G. and WANDSCHNEIDER, K. (2005). The Baring Crisis and the Brazilian Encilhamento, I 889-I 89I: an early example of contagion among emerging capital markets. Financial History Review, I2(2), pp. I99-225.

TURNER, J. (2014). Banking in Crisis: The Rise and Fall of British Banking Stability, 1800 to the Present. Cambridge: Cambridge University Press.

WALSH, B. (I999). The persistence of high unemployment in a small open labour market: the Irish case. In F. Barry (ed.), Understanding Ireland's Economic Growth. London: Macmillan. 